\title{
Socioeconomic Determinants of Farmers using Social Network in Advancing Agribusiness in Anambra State, Nigeria
}

\author{
Ekeke, N.C ${ }^{1}$, Isibor, C.A. ${ }^{2}$, Nkamigbo, D.C. ${ }^{3}$ \\ ${ }^{1,2,3}$ Department of Agricultural Economics and Extension, Faculty of Agriculture, Nnamdi Azikiwe University, \\ Awka, Nigeria.
}

Corresponding Author: Nkamigbo, D.C.

\begin{abstract}
The study examined socioeconomic determinants of farmers' using social network in advancing agribusiness in Anambra State, Nigeria. Specifically, it described the socioeconomic characteristics of the respondents, identified various social networks available and level of usage among the respondents, determined the influence of socio-economic factors on net marketing income among the respondents and identified the challenges of social network in advancing agribusiness by the respondents. Multi-stage, purposive and simple random methods were used to select one hundred and sixty respondents for the study. Data were collected from primary source. Primary data were collected using structured questionnaire. Collected data were analyzed by means of descriptive statistics, and multiple regression techniques. From the result, findings on the socioeconomic characteristics showed that farmers are relatively young, energetic, are in computer age and able to use phone and other devices to advance agribusiness in their area and beyond for optimum profit. Farmers are educated, married and there is male dominance in the use of social network in advancing agribusiness in the study area. The result showed that WhatsApp, Facebook, You Tube and messenger were mostly used in advancing agribusiness in the study. Marital status, education, household size, means of delivery and marketing cost influenced net marketing income earned by the respondents.

Lack of awareness, poor assessment of social network and costly charge of data when accessing the social network were perceived as
\end{abstract}

the main constraints affecting agribusiness. Measures will be taken by appropriate authorities to reduce the tariff of data in accessing social network. Farmers should be trained more on the use of social network to advance their produce to the world. Network providers should of necessity improve their services to enable social network users to be effective.

Keywords: Determinants, Social network, Agribusiness

\section{INTRODUCTION}

Agriculture is an engine room for sustaining growth of Nigeria economy and still remains the mainstay of our economy by providing food for the teeming population, creates jobs as well as wealth, raw material for the industrial sector and foreign earnings (Isibor and Nkamigbo, 2019). Agriculture is one of the affective ways to alleviate hunger, poverty and remained one of the top and widely profitable business sector (Amungwa and Baye, 2014 and Idu, Ajah, Alabi and Nnaji, 2021). Over the years, agriculture has evolved from subsistence to modern agriculture, whereby farmers are involved in the business of agriculture. Agribusiness is the business sector encompassing farming and farming-related commercial activities. It involves all the steps required to send agricultural produce from the farm to the consumer. Agribusiness is encompassing as it covers all aspects of commercial 
agriculture. In the past few years, policies have been put in place to ensure the rapid growth and development of the Nigerian agribusiness sector. However in Agriculture, the use of Social network has become a powerful tool that connects millions of people globally from the comfort of our homes, social network is revolutionizing the way business is carried out, bringing new ways of communication and exchange of information across the globe. Social network is now a mainstream form of communication around the world, and continues to grow in popularity with the increase in the number of smart phones, and the ease of use (Kipkurgat, Michael and Silas, 2016). Social network is different from social media. Social network is a platform for communicating with one another.

Guarino (2012) opined that social network is a medium for interaction using communication technologies that is mostly internet based and involves participatory and user generated content. (Balkrishna and Deshmukh, 2017) viewed social network as web-based services that allow individuals to (1) construct a public or semi-public profile within a bounded system, (2) articulate a list of other users with whom they share a connection, and (3) view and traverse their list of connections and those made by others within the system. The nature and nomenclature of these connections may vary from site to site. Social network increases two way communications. Farmers are using social network because it has ability to connect with farmers, agribusiness and agricultural experts over a geographical distance. Up to certain extent, social network in agricultural marketing provides solutions to the agribusiness problems (Balkrishna and Deshmukh, 2017). According to (Amade, 2017), social network is usually adjudged as a major external platform consisting of such tools as Facebook, Twitter, LinkedIn, YouTube, Messenger, Wichteh, Google Plus, WhatsApp, However, a handful of internal social platforms exist within organizations which are specifically tailored to suit some projects.

Agricultural business includes all the activities within the agricultural food and natural resource industries that are involve in the production of food and fiber. Individual agribusiness may sell items to farmers for production, provide service to other agricultural business or be engaged in the marketing, transporting, processing and distribution of agricultural products (Saunders, 2012). In Nigeria, Agribusiness provides people with food, clothing and shelter. It helps in Nigeria economy by providing jobs for millions of people in science, research, engineering, education, advertisement, government agencies, trade organizations and commodity. In Agricultural business activities, social network cannot be left behind to achieve agricultural development. The use of social network in agricultural business is increasing rapidly nowadays. Many service provider companies are giving better facilities to the farmers (Mburu, 2013).

There are needs for dynamism in agricultural sector in Nigeria, especially in Anambra State. Nigeria has a total land area of 82 million arable hectares out of its total land area of 91 million hectares. There are hundreds of different food crops like maize, yam, millet, beans and potatoes that are being produced by Nigerians farmers each year. However, their output is not enough to meet the nations demand. Also, Nigerian population is increasing rapidly and there is need for effective communication through networking and information (Mudiwa, 2017)

\section{MATERIAL AND METHODS}

The study was carried out in Anambra State. Anambra is a state in southeastern Nigeria. The Sate is known for production and marketing of several raw materials and agro products in different parts of the state. Some of the crops produce and marketed in the state include oil palm, maize, rice, yam, groundnut, cassava, garri, cucumber, watermelon, melon, potato, 
greenbeans (akidi), pigeon pea, soyabean and livestock such as fish, goat, sheep, poultry and cattle are also raised. It is an agrarian state with high crop production and marketing activities. It is situated on a generally low elevation on the eastern side of the river Niger, sharing boundaries with Delta State to the west Imo, Abia and Rivers States to the south, Enugu state to the East and Kogi State to the North. The state occupies an area of about 4,844km2. Geographically, the state lies within longitude 50551 and $60421 \mathrm{~N}$.

The population of the state is 4,182,232 with 863 sqkm density (NPC, 2006). The state has several daily markets both in the rural and urban areas where agricultural products are sold. It consists of twenty-one (21) Local government areas (LGAs) and four agricultural zones namely Awka (Awka North, Awka South, Dunukofia, Njikoka, Aniocha), Aguata (Orumba south, Orumba North, Aguata, Nnewi North, Nnewi South), Onitsha (Onitsha North, Onitsha South, Ihiala, Ekwusigo, Idemili North, Idemili South, Ogbaru) and Anambra (Anambra North, Anambra west, Oyi, Ayamelum) zones. The state is embedded by five major rivers and their tributaries. These are River Niger, Anambra River, Ezu River, Idemili River and Ulasi River. However, there are smaller streams like Oji, Nkisi and Obizi. In-land valley, ponds and lakes occur with the Agulu Lake draining a collection of towns in the State (Nkamigbo and Isibor, 2019). The rainy season occurs from the month of November ton February. The annual rainfall ranges from $1400 \mathrm{~mm}$ in the North to 2500 $\mathrm{mm}$ in the South with temperature of $25 \mathrm{oC}$ $-35 \mathrm{OC}$.

\section{Population of the Study}

The population of the study was the entire registered farmers in the State. According to Anambra State Agricultural Development Programme, the State have over (120401) one hundred and twenty thousand, four hundred and one registered farmers that have access to modern social networks.

\section{Sampling techniques}

A multi-stage sampling procedure was used to select respondents for the study. Stage1: Two Agricultural zones namely Aguata and Onitsha zones were purposively selected due to high activity of farming operations and dense populations that can generate disposable farm produce and profit. Stage II: Two blocks were randomly selected from each zone making it a total of 4 blocks (Orumba North, Orumba South, Ogbaru and Ekwusigo)

Stage III: Four circles were randomly selected from each of the blocks earlier selected making it a total of sixteen circles

(Omogho, Awgbu, Ufuma Ndiokpala, Umunze, Ogboji, Ogbunka, OwerreEzukala, Atani, Akili-Ozizor, Ogwu-Ikpele, Ogwu-Aniocha, Ozubulu, Oraifite, Ichi and Ihembosi.

Stage IV: A random sampling was made from each of the sixteen circles selected, making it a total of one hundred and sixty respondents which is the sample size. Sampling was done in proportion to the sample size.

\begin{tabular}{|c|c|c|c|c|}
\hline AGRIULTURAL ZONES & BLOCKS & CIRCLES & RESPONDENTS & TOTAL \\
\hline \multirow[t]{2}{*}{ AGUATA } & ORUMBA NORTH & $\begin{array}{l}\text { Omogho } \\
\text { Awgbu } \\
\text { UFUMA } \\
\text { NDIOKPALA }\end{array}$ & $\begin{array}{l}8 \\
10 \\
11 \\
13\end{array}$ & 42 \\
\hline & ORUMBA SOUTH & $\begin{array}{l}\text { UMUNZE } \\
\text { OGBOJI } \\
\text { OGBUNKA } \\
\text { OWERRE-EZUKALA }\end{array}$ & $\begin{array}{l}11 \\
6 \\
8 \\
13 \\
\end{array}$ & 38 \\
\hline \multirow[t]{2}{*}{ ONITSHA } & OGBARU & $\begin{array}{l}\text { ATANI } \\
\text { AKILI-OZIZOR } \\
\text { OGWU-IKPELE } \\
\text { OGWU-ANIOCHA }\end{array}$ & $\begin{array}{l}11 \\
13 \\
11 \\
10\end{array}$ & 45 \\
\hline & EKWUSIGO & $\begin{array}{l}\text { OZUBULU } \\
\text { ORAIFITE } \\
\text { ICHI } \\
\text { IHEMBOSI }\end{array}$ & $\begin{array}{l}6 \\
8 \\
11 \\
10\end{array}$ & 35 \\
\hline
\end{tabular}




\section{Method of Data Analysis}

Data were analyzed using descriptive analysis such as tables, mean, frequency distribution multiple regression analysis and mean ranking.

\section{Multiple Regression Model}

The model was used to measure the influence of socio-economic characteristics on net marketing income of farmers using social network in advancing agribusiness. Social-economic characteristics (SEC) of the respondents namely age (AGE), gender (GEN), marital status (MRS), education (EDU), Source of finance (SOF), household size (HOS), Membership of trade union (TOU), Branding of product (BOP), Experience (EXP), means of delivery (MOD) and Marketing cost (MKS).

NMISN=Net Marketing Income of Social Network

$\mathrm{AGE}=$ Age in years

GEN $=$ Gender (dummy: male $=0$; female $=$ 1)

MRS = Marital status

$\mathrm{EDU}=$ Educational level

$\mathrm{SOF}=$ Source of finance

HOS $=$ Household size (number of persons living together)

TOU $=$ Membership of trade union (dummy: member $=0$, non member $=1$ )

$\mathrm{BOP}=$ Branding of product.(dummy: branding $=0$, non branding $=1$ )

$\mathrm{EXP}=$ Experience

MOD $=$ Method of delivery

MKS $=$ Marketing cost

$\mathrm{e}=$ Stochastic error term.

It is implicitly represented below as

NMISN

$\left(\mathrm{AGE}_{1}, \mathrm{GEN}_{2}, \mathrm{MRS}_{3}, \mathrm{EDU}_{4}, \mathrm{HOS}_{5}\right.$,

$\mathrm{SOF}_{6}, \mathrm{TOU}_{7,} \mathrm{BOP}_{8}, \quad \mathrm{EXP}_{9}, \mathrm{MOD}_{10}, \mathrm{MKS}_{11}$ $\left.\ldots . . . \beta_{\mathrm{n}}\right)$

thus;

The explicit form is represented

Linear form:

NMISN $=\beta_{0}+\beta_{1} \mathrm{AGE}_{1}+\beta_{2} \mathrm{GEN}_{2}+$ $\beta_{3} \mathrm{MRS}_{3}+\beta_{4} \mathrm{EDU}_{4}+\beta_{5} \mathrm{SOF}_{5}+\beta_{6} \mathrm{HOS}_{6}+$ $\beta_{7} \mathrm{TOU}_{7}+\beta_{8} \mathrm{BOP}_{8}+\beta_{9} \mathrm{EXP}_{9}+\beta_{10} \mathrm{MOD}_{10}+\beta_{11}$ $\mathrm{MKS}_{11}+\mathrm{e}_{1}$
Semi Log form

NMISN $=\beta_{0}+\beta_{1} \log \mathrm{AGE}_{1}+\beta_{2} \log \mathrm{GEN}_{2}+$ $\beta_{3} \log \mathrm{MAS}_{3}+\beta_{4} \mathrm{EDU}_{4}+\beta_{5} \mathrm{SOF}_{5}+\beta_{6} \mathrm{HOS}_{6}+$ $\beta_{7} \mathrm{TOU}_{7}+\beta_{8} \mathrm{BOP}_{8}+\beta_{9} \mathrm{EXP}_{9}+\beta_{10} \mathrm{MOD}_{10}$ $+\beta_{11} \mathrm{MKS}_{11}+\mathrm{e}_{1}$

Double Log form:

LogNMISN $=\beta_{0}+\beta_{1} \log \mathrm{AGE}_{1}$ $+\beta_{2} \log \mathrm{GEN}_{2}+\beta_{3} \log \mathrm{MAS}_{3}+\beta_{4} \log \mathrm{EDU}_{4}+$ $\beta_{5} \log \mathrm{SOF}_{5}+\beta_{6} \log \mathrm{HOS}_{6}+\beta_{7} \log \mathrm{TOU}_{7}+\beta$ ${ }_{8} \log \mathrm{BOP}_{8}+\beta{ }_{9} \log \mathrm{EXP}_{9}+\beta_{10} \log \mathrm{MOD}_{10}+$ $\beta_{11} \log \mathrm{MKS}_{11}+\mathrm{e}_{1}$

Exponential form:

$\log$ NMISN $=\beta_{0}+\beta_{1} \mathrm{AGE}_{1}+\beta_{2} \mathrm{GEN}_{2}+$ $\beta_{3} \mathrm{MRS}_{3}+\beta_{4} \mathrm{EDU}_{4}+\beta_{5} \mathrm{SOF}_{5}+\beta_{6} \mathrm{HOS}_{6}+$ $\beta_{7} \mathrm{TOU}_{7}+\beta_{8} \mathrm{BOP}_{8}+\beta_{9} \mathrm{EXP}_{9}+\beta_{10} \mathrm{MOD}_{10+}$ $\beta_{11} \mathrm{MKS}_{11}+\mathrm{e}_{1}$.

\section{Model specification.}

The budgetary technique was used to determine the profitability of farmers using social network to advance agribusiness.

$$
\begin{aligned}
& \text { NMISN }=\underset{i-1}{\sum_{i=1}^{n} \mathrm{P}_{\mathrm{yi}}} \quad \mathrm{Y}_{\mathrm{i}} \\
& \left(\sum_{k=0}^{n} \mathrm{P}_{\mathrm{xij}} \mathrm{X}_{\mathrm{ij}}+\sum_{i-1}^{r} \mathrm{~F}_{\mathrm{ij}}\right)
\end{aligned}
$$

Where $\sum=$ sum

$\mathrm{P}_{\mathrm{yi}} \mathrm{Y}_{\mathrm{i}}=$ unit price $\times$ quantity of $\mathrm{i}^{\mathrm{t}^{\text {th }}}$ respondents sales $=$ Total revenue $(\mathrm{TR})$ for $i^{\text {th }}$ respondent.

$\mathrm{P}_{\mathrm{xij}} \mathrm{X}_{\mathrm{ij}}=$ Prices $\mathrm{X}$ quatities of $\mathrm{i}^{\text {th }}$ respondents variable inputs $=$ total variable cost $($ TVC $)$ for $\mathrm{j}^{\text {th }}$ respondent.

$F_{i j}=$ Depreciation values of equipment, annual rent for store, interest on loan, for $j^{\text {th }}$ respondents $=$ Total fixed cost (TFC) for $\mathrm{j}^{\text {th }}$ respondent.

$\mathrm{TC}=$ Total cost $(\mathrm{TVC}+\mathrm{TFC})$.

The marketing efficiency of farmers' using social network to advance agribusiness was determined using Shepherd-Futrell technique.

\section{RESULTS AND DISCUSSION \\ Socioeconomic characteristics of the respondents}

Socioeconomic characteristics of the respondents in Table 2 indicates that 
majority of the farmers are within 30-39 years $(50 \%)$ with the mean age of 38.4 . This implies that the farmers were relatively young, energetic, are in computer age and able to use phone and other devices to advance agribusiness in their area and beyond for optimum profit. This agrees with (Jiriko, 2015, and Idu, Ajah, Alabi and Nnaji, 2021) who reported that age had a positive relationship with ability to use ICT utilization and social network in their area. This is at variance with (Khan, Rahman, and Oazi, 2016 and Inegbedion et al.2020 and) who stated that there is no significance influence of age in the usage of social network in enhancing the turnover of agricultural products. The results showed that majority of the respondents were married 60\%. This agrees with Irvin (2021) who reported an increased usage of social network among married. This implies that the respondents will engage the services of the family members in advancing agribusiness in the study area as most children are in tune with the use of android phone. It could be seen from the table that majority of the respondents had higher school certificates. This implies that they can easily access network to advance their businesses with social network and make profit. This agrees with (Kipkurgat et al, 2016) who stated that farmers are knowledgeable enough to understand and access information. This is at variance with (Wangu, 2014) who stated that majority were of middle education levels. It could be seen from the table that the respondents have a household size of 1-3 members $61 \%$. The source of fund of the respondents reveals that personal savings was $34.4 \%$, Friends and relative was $43 \%$, Isusu was $18.6 \%$ and microfinance was $3.75 \%$. This implies that in the study area people borrow less to sponsor their business. The study reveals slight male dominance $56.25 \%$ in the use of social network in advancing agribusiness than female $43.12 \%$ in the study area. This is in agreement with (Balkrishna and Desshmukh, 2017) who reported a male dominance than female in social media usage. Also the study reveals that $93.75 \%$ of the members are not member of trade union in the study area. Also the study reveals that $36.25 \%$ of the respondents have 1-4 years of business experience in the use of social network in advancing agribusiness, 5- 8 years $55 \%$ while 9-12 years of experience is $6.23 \%$. This is an indication that the use of social network in advancing agribusiness is gradually gaining ground in the study area. The study revealed the use of commercial vehicle $(55.65 \%)$ in delivery. This implies that majority of the respondents patronize commercial means of delivery. Also, from the study $65 \%$ brand their products while $35 \%$ do not brand their products. This is in agreement with (Balkrishna and Deshmukh, 2017) who noted high rate of branding of products by the farmers.

Table 2 Socioeconomic characteristics of the respondents

\begin{tabular}{|l|l|l|l|}
\hline Variables & Frequency $(\mathbf{n}=160)$ & Percentage (\%) & Mean \\
\hline Age & 21 & 13.13 & 38.4 \\
\hline $20-29$ & 80 & 50 & \\
\hline $30-39$ & 42 & 26.25 & \\
\hline $40-49$ & 10 & 6.25 & \\
\hline $50-59$ & 7 & 4.38 & \\
\hline 60 and above & 160 & 100 & \\
\hline Total & \multicolumn{5}{|l|}{} \\
\hline Marital Status & 40 & 25.00 & \\
\hline Single & 96 & 60.00 & \\
\hline Married & 24 & 15.00 & \\
\hline Divorced & 160 & 100 & 15.4 \\
\hline Total & 29 & 18.13 & \\
\hline Education Status & 40 & 25 & \\
\hline $0-6$ & 91 & 56.88 & \\
\hline $7-12$ & 160 & 100 & \\
\hline $13-18$ & & & \\
\hline Total & \multicolumn{5}{|l|}{} \\
\hline
\end{tabular}


Ekeke, N.C et.al. Socioeconomic determinants of farmers using social network in advancing agribusiness in Anambra state, Nigeria.

\begin{tabular}{|c|c|c|c|}
\hline \multicolumn{4}{|c|}{ Table 2 Continued... } \\
\hline \multicolumn{4}{|l|}{ No of Household } \\
\hline $1-5$ & 99 & 61.88 & \\
\hline $6-10$ & 48 & 30 & 7 \\
\hline $11-15$ & 11 & 6.88 & \\
\hline $16-20$ & 02 & 4.38 & \\
\hline Total & 160 & 100 & \\
\hline \multicolumn{4}{|l|}{ Sources of Finance } \\
\hline Personal savings & 55 & 34.4 & \\
\hline Friends and relative & 69 & 43.1 & \\
\hline Isusu & 30 & 18.6 & \\
\hline Commercial Bank & - & - & \\
\hline Microfinance Bank & 6 & 3.75 & \\
\hline Total & 160 & 100 & \\
\hline \multicolumn{4}{|l|}{ Gender } \\
\hline Male & 90 & 56.25 & \\
\hline Female & 69 & 43.12 & \\
\hline Total & 160 & 100 & \\
\hline \multicolumn{4}{|l|}{ Trade Union } \\
\hline Member & 10 & 6.25 & \\
\hline Non member & 150 & 93.75 & \\
\hline Total & 160 & 100 & \\
\hline \multicolumn{4}{|l|}{ Years in business } \\
\hline $1-4$ & 58 & 36.25 & 16 \\
\hline $5-8$ & 88 & 55.00 & \\
\hline $9-12$ & 10 & 6.25 & \\
\hline 13 and above & 4 & 2.50 & \\
\hline Total & 160 & 100 & \\
\hline \multicolumn{4}{|c|}{ Branding of Products } \\
\hline Yes & 104 & 65 & \\
\hline No & 56 & 35 & \\
\hline Total & 160 & 100 & \\
\hline \multicolumn{4}{|l|}{ Means of Delivery } \\
\hline Personal Car & 16 & 10 & \\
\hline Bike & 55 & 34.38 & \\
\hline Commercial & 89 & 55.63 & \\
\hline Total & 160 & 100 & \\
\hline
\end{tabular}

Various social networks available and level of use.

From the study, Facebook,Twitter, WhatsApp, YouTube, Google plus, LinkedIn, To go, We chat, Instagram and Messenger were identified as the social network available in the study area. From the study it could be seen that the respondents' access to these social network in advancing agribusiness in the study area were as follows; Facebook $25 \%$. (Vassiliadory, Vogiatzi, Theodore and Mpoutakidis, 2021) who reported Facebook coming first among other social network. (Balkrish and Deshmukh, 2017) who reported that most respondents use whatsapp as their favorites most social network and mostly preferred for related groups. You tube 20\% and Messenger $1.87 \%$. It could be seen from the study that respondents have more access to WhatsApp and Facebook which have gain ground in the study area than You Tube and Messenger. This maybe as a result that WhatsApp and Face book are easier to operate and uses less data than You tube. Other social networks identified in the study area were not agribusiness friendly.

Table 3 Various social networks available and level of usuage

\begin{tabular}{|l|l|l|}
\hline Variables & Frequency (\%) & Percentage \% \\
\hline Face book & 40 & 25 \\
\hline Twitter & & \\
\hline WhatsApp & 85 & 53.125 \\
\hline Youtube & 32 & 20 \\
\hline Google Plus & - & \\
\hline LinkedIn & - & \\
\hline To go & - & \\
\hline We Chat & - & \\
\hline Instagram & - & \\
\hline Messenger & 3 & 1.87 \\
\hline & 160 & 100 \\
\hline
\end{tabular}

Source: Field survey, 2021.

\section{Influence of socioeconomic}

\section{characteristics on net marketing income of farmers using social network to advance agribusiness.}

Table 4 shows output of the four functional forms of the regression model for 
predictors of net marketing income of farmers' using social network to advance agribusiness. The result indicated that output of the Double log form gave the best result in terms of number of significant predictors, signs and sizes of the predictors as well as the values of F- statistic, R2, and R2 adjusted and was chosen as the lead equation. The coefficient of the multiple determination (R2)78.0\% meant $78 \%$ of the variation in the profit was explained by the variations in the independent variables while the remaining $22 \%$ was due to error. The F-statistic value of 46.87 was significant and confirms to overall significance of the regression analysis. NMISN=15.57- $\quad 0.03 \mathrm{AGE} \quad+0.41 \mathrm{GEN}$ $+0.12 \mathrm{MRS}+0.06 \mathrm{EDU}+0.03 \mathrm{HOS}+$ $0.04 \mathrm{SOF}-0.01 \mathrm{TOU}+0.01 \mathrm{BOP}+0.07 \mathrm{EXP}$ $+3.29 \mathrm{MOD}-15.57 \mathrm{MKS}$.

Out of eleven independent variables included in the model, age, gender, marital status, education, household size, source of finance, membership of trade union, branding of product, years of experience , Means of delivery and marketing cost only five namely (marital status, education, household size, means of delivery and marketing cost) influenced net marketing income earned by the respondents. The remaining six (age, gender, source of finance, membership of a trade union, branding of product and years of experience) were not significant.

The coefficient of marital status had a positive and statistically significant effect on the net marketing income at $10 \%$ probability level. This implies that married family have enough labour force for logistics for the advancement in the use of social network in advancing agribusiness. The coefficient of educational level had positive and statistically significant effect on the net marketing income of social network at $10 \%$ probability level. This implies that a unit in increase in education may lead to increase in net returns. Educated people are more enlightened and thereby are well conversant in the use of android phone and it's like and also efficient in advancing agribusiness using social network. The coefficient of household size was positive and had a significant effect on net marketing income in the use of social network at $10 \%$ probability. This implies that the members of the household do help in overall disposal of the farm produce which increases the family income. The coefficient of source finance was positive and had a significant effect on net marketing income in the use of social network at $10 \%$ probability. This implies that adequate financing is a tool in advancing agribusiness through social network and less of borrowing from financial institutions leads to better net income and less stress in the enterprise. The coefficient of mode of delivery was positive and had a significant effect on net marketing income in the use of social network at $1 \%$ probability. This implies that effective delivery improves agribusiness.

\begin{tabular}{|c|c|c|c|c|c|}
\hline & Predictor & Linear & Exponential & Semilog & Double log \\
\hline & AGE & $0.16(0.66)$ & $0.002(0.37)$ & $0.49(0.97)$ & $0.03(0.41)$ \\
\hline & GEN & \begin{tabular}{|l|}
$-4.94(0.45)$ \\
\end{tabular} & $-0.040(0.30)$ & $-3.68(0.60)$ & 0.41(0.15) \\
\hline & MRS & \begin{tabular}{|l|l|}
$8.92(0.07) *$ \\
\end{tabular} & \begin{tabular}{|c|}
$0.04(0.25)$ \\
\end{tabular} & $11.34(0.04)^{*}$ & $0.12(0.01)^{*}$ \\
\hline & EDU & $1.49(0.048)$ & $0.01(0.005)^{* *}$ & $14.43(0.08)^{*}$ & $0.06(0.08)^{*}$ \\
\hline & HOS & $1.74(0.06) *$ & $0.01(0.05)^{* * *}$ & $7.21(0.17)$ & $0.03(0.05) *$ \\
\hline & SOF & \begin{tabular}{|l|}
$5.62(0.02) *$ \\
\end{tabular} & $0.02(0.02)^{*}$ & $6.02(0.02)^{*}$ & (0.04(0.38) \\
\hline & TOU & \begin{tabular}{|l|}
$5.59(0.38)$ \\
\end{tabular} & \begin{tabular}{|l|}
$0.02(0.56)$ \\
\end{tabular} & $7.76(0.27)$ & \begin{tabular}{|l|}
$-0.01(0.90)$ \\
\end{tabular} \\
\hline & BOP & $1.93(0.76)$ & \begin{tabular}{|c|}
$-0.01(0.79)$ \\
\end{tabular} & 3.30(0.64) & 0.01(0.73) \\
\hline & EXP & \begin{tabular}{|l|l|}
$0.61(0.57)$ \\
\end{tabular} & \begin{tabular}{|l|}
$-0.03(0.61)$ \\
\end{tabular} & $2.22(0.67)$ & $0.07(0.22)$ \\
\hline & MOD & \begin{tabular}{|l|}
$7.65(0.12)$ \\
\end{tabular} & $-0.047(0.11)$ & $9.55(0.33)$ & $3.29(0.000) * * *$ \\
\hline & MKC & $1.20(0.000)^{* * *}$ & $0.01(0.000) * * *$ & $494.69(0.000)^{* * * *}$ & $15.57(0.000)^{* * * *}$ \\
\hline & CONSTANT & 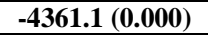 & $1.01(0.000)$ & $-2930(0.000)$ & $-15.57236(0.000)$ \\
\hline & $\overline{\mathbf{R}^{2}}$ & 76.0 & 76.0 & 71.0 & 78.0 \\
\hline & ADJ.R ${ }^{2}$ & 0.74 & 0.73 & 0.69 & $\mathbf{0 . 7 5 3 4}$ \\
\hline & PROB.>F & 40.17 & 41.25 & 32.39 & 46.87 \\
\hline & ROOT MSE & 36.49 & 36.188 & 39.861 & 0.24119 \\
\hline
\end{tabular}


The coefficient of marketing cost was positive and had a significant effect on net marketing income in the use of social net -work at $1 \%$ probability. This implies a positive relationship between marketing cost and net marketing income. That is, the farmers who invested more money in their enterprise earned higher profit. This agrees with Inegbedion et al. (2012) who reported that there is enhancement of farmers' sales turn-over which is relative to net marketing income of the respondents

\section{Constraints to farmers using social network in advancing agribusiness}

The constraints associated with farmers using social network in advancing agribusiness in the study area were shown in Table 5 The findings showed that lack of awareness $(M=3.35)$ were perceived as the most prevalent constraints in the use of social media to advance agribusiness in the study area. Many are not aware of this modern device like phones to create awareness and market agricultural produce. Another constraint of importance in the study area is poor assessment of social media $(\mathrm{M}=3.20)$ by intending customers. This is in agreement with Guana, Obi, Egbara, Omedeomero and Akuabor, (2017) who reported that many youths still lack skills and competence in using social network for agricultural development. Costly charge of data when accessing the social media $(\mathrm{M}=3.05)$ ranks $3 \mathrm{rd}$ among the constraints in the use of social media in advancing agribusiness in the study area which is in agreement with Kipkurgat, Onyiego who reported costly charges when accessing the internet. Many can't afford to be on line constantly to know the trend in agribusiness due to insufficiency of data. This is adversely affecting agribusiness. Poor network services $(\mathrm{M}=3.0)$ is another constraints that do affect the use of social media in advancing agribusiness in the study area which is in tandem with Kipkurgat et al. (2016) who reported poor network access as the main constraints in their area. It is almost the order of the day to see variation in network supply in this country at large. Other constrains of less importance were poor power supply and use as a deceptive means.

Table 5 Constraints to farmers using social network in advancing agribusiness

\begin{tabular}{|l|l|l|}
\hline Constraints & $\begin{array}{l}\text { Mean } \\
\text { score }\end{array}$ & Rank \\
\hline Poor network services & 3.0 & $4^{\text {th }}$ \\
\hline $\begin{array}{l}\text { Costly charge on data when accessing the } \\
\text { social network }\end{array}$ & 3.05 & $3^{\text {rd }}$ \\
\hline Poor usage of phones & 2.48 & $5^{\text {th }}$ \\
\hline Poor assessment by intending customers & 3.20 & $2^{\text {nd }}$ \\
\hline Use as a deceptive means & 2.30 & $7^{\text {th }}$ \\
\hline Poor power supply & 2.40 & $6^{\text {th }}$ \\
\hline Lack of awareness & 3.35 & $1^{\text {st }}$ \\
\hline
\end{tabular}

Source: field survey, 2021.

\section{Summary}

The study examined socioeconomic determinants of farmers using social network in advancing agribusiness in Anambra State, Nigeria. The study specifically described the socio-economic characteristics, identified various social network available and level of use among the respondents in study area, determined the influence of socioeconomic factors on net marketing income of farmers using social network in advancing agricultural business and challenges of social network in advancing agribusiness by the respondents in the study area.

Multi-stage, purposive and simple random methods were used to select one hundred and sixty respondents for the study. Two Agricultural zones were purposively selected, two blocks were randomly selected from each zone making it a total of 4 blocks. Four circles were randomly selected from each of the blocks earlier selected making it a total of sixteen circles and finally ten respondents were randomly selected from each of the sixteen communities selected, making it a total of one hundred and sixty respondents which is the sample frame.

Primary data were collected by means of structured questionnaire administered to respondents by personal interview. Data were analyzed using descriptive statistics (mean, frequency distribution, percentages, mean ranking and ratio) and multiple regression. 
Findings on the socioeconomic characteristics showed that farmers are relatively young, energetic, are in computer age and able to use phone and other devices to advance agribusiness in their area and beyond for optimum profit. It also revealed that the farmers are educated, married and there is male dominance in the use of social media in advancing agribusiness in the study area. Facebook, twitter, WhatsApp, YouTube, Google plus, LinkedIn, To go, We chat, Instagram and messenger were identified as the social network available while WhatsApp, Facebook, you tube and messenger were mostly used in advancing agribusiness in the study.

Out of eleven independent variables included in the model, age, gender, marital status, education, household size, source of finance, membership of trade union, branding of product, years of experience , means of delivery and marketing cost only five namely (marital status, education, household size, means of delivery and marketing cost) influenced net marketing income earned by the respondents. The constraints associated with farmers using social network in advancing agribusiness showed that lack of awareness, poor assessment of social network and costly charge of data when accessing the social network were perceived as the main constraints affecting agribusiness.

\section{CONCLUSION}

The assessment of socioeconomic determinants of farmers using social network in advancing agribusiness in Anambra State, Nigeria is a profitable venture indicating the high use of WhatsApp, face book, you tube and messenger. If measures will be taken to address the constraints, their level of income would improve.

\section{Acknowledgement: None}

\section{Conflict of Interest: None}

Source of Funding: None

\section{REFERENCES}

1. Amade, B. (2017). The Impact of Social Media in Achieving Effective Communication in Construction Project" European Project management journal,7(3), 32-39.

2. Amungwa, F.A., Baye, F.M. (2014). Appriaisal of the Agricultural Extension System of family Farm Schoos in Cameroun. Asian of Agricultural Extension System. Asian Journal of Agricultural Economics andSociology,2(2), 530-544.

3. Balkrishna, B.B. and Deshmukh, A.A. (2017). A Study on Role of social media in Agricultural Marketing and its scope, social challenge. Global Journal of Management and Business Research, E Marketing, 17(1), 1-5.

4. Cline, M.M,(2011).The expansion of social media in agriculture. A user profile of Twitters@agchat, @followafarmer and @ rafflemesdia followers".

5. Food and Agricultural Organization (FAO)(2015). Global food losses and food waste-extent, causes and prevention Rome FAO OF UNO.

6. Guarino .J. (2012), Social Media for project Managers. Evolutionary IT. Retrieved and assessed from http:www. Evolutionaryit.com 24th November,2016.

7. Guana, S., Obi,I., Egbara, Omedeomero, S. and Akuabor, N.T. (2017). Social media, youth and Agricultural Development in Niger Delta Region, Nigeria. International Journal of Communication on interdisciplinary journal of communication Studies, 22, 27-48.

8. Isibor, A.C. and Nkamigbo, D.C. (2019). Economic determinants of loan repayment to largeand small scale farmer-beneficiaries of bank of agriculture loans from 2010-2016 in Anambra State, Nigeria. Intl Journal of Agric Policy and Research, 7(4), 91-99.

9. Inegbedion, H., Inegbedion, E., Asaleye, A., Obadiaru, E., Asamu. F. (2020). Use of social media in the marketing of Agric production and farmers turnover in South South Nigeria, FI000 Research, 2(1), 1-8.

10. Idu, E.E., Ajah, A., Alabi, T. and Nnaji, J.N. (2021). Determinants of Social media usage in agriculture among youths in the Federal Capital Territory, Abuja. Direct Research Journal of Agriculture and Food Science, 9, 36-41. 
Ekeke, N.C et.al. Socioeconomic determinants of farmers using social network in advancing agribusiness in Anambra state, Nigeria.

11. Khan, A., Rahman, A, and Qazi, L. (2016). The Relationship Between internet Usage, Socioeconomic Status, Subjective Health and Social Status. Business and Economic Review, 8, 69.

12. Mburu P, (2013). Factors influencing Access to Agricultural information by small holder farmers through ICT Channels in Denya Location Kiambu Country university of Nairobi, Master Thesis.

13. Mudiwa, B.(2017).Theories of Smallholders Agribusiness Entrepreneurship in the Africa Context: A critical Review" International journal of Arts and Humanities (IJAH) Barhir. Dar Ethopia, 6(1), 221-236.

14. Nkamigbo, D.C and Isibor, A.C. (2019). Inter-Market Price Spread and Determinants of Net Farm Income in Watermelon marketing in Anambra .State, Nigeria. . International Journal of Agricultural Policy and Research,7(4), 100-107.

15. National Population Commission(2006). Census Report, NPC Commision, Abuja, Nigeria

16. Kipkurgat, T., Michael O. and Siilas. C (2016). Impact of Social Media on Agricultural Extension in Kenya: District. International Journal of Extension and Rural Development Studies,3(1), 30-36.

17. Saurders, M. (2012): Research methods in Business Students. Prentice Hall, London.
18. Siemeon .E.,Sitalaskshmu, P., Doriane kouane\& Wastson ,Tom.(2011).The History of Social media and its Impacts on Business. The journal of Applied Management and Enterpreneurship, 16(3),23-27.

19. Vassilladou, S., Vogaiatzi, M., Amygdalas, T. Et al. (2011). The use of social media among students of technology, agriculture and their role in providing agribusiness. In M. Salampasis, A. Matopoulos (eds); proceedings of the International conference on information and communication technologies for sustainable agri-production and erosion HAICTA, Skiathos.

20. Wangu, C. (2014). Use of social media as a source of agricultural information by small holder farmers: a case study of Lower Kabete, Kiambu county. Unpiblished M Sc Thesis, Department of Communication Studies, School of Journalism and Mass Communication, University of Nairobi.

How to cite this article: Ekeke, N.C, Isibor, C.A., Nkamigbo, D.C. $\quad$ Socioeconomic determinants of farmers using social network in advancing agribusiness in Anambra state, Nigeria. International Journal of Research and Review. 2021; 8(8): 138-147. DOI: https://doi. org/10.52403/ijrr.20210820 